\title{
A espécie do reprodutor (equinos $x$ asininos) e o sexo da cria sobre o período de gestação em éguas
}

Gabriela Bertaiolli Zoca, Gabriel de Carli dos Santos, Thiago Martins, Eneiva Carla Carvalho Celeghini, Carla Patricia Teodoro de Carvalho, Renata Lançoni, Thyago Escodro Dercoli, Rubens Paes de Arruda'

Faculdade de Medicina Veterinária e Zootecnia, Universidade de São Paulo (USP), Pirassununga, SP, Brasil

*Autor correspondente

e-mail: arrudarp@usp.br

\section{Resumo}

O período de gestação das éguas está sujeito a grandes variações, uma vez que fatores referentes à raça, idade, níveis nutricionais, número de partos, sexo e espécie da cria e ambiente (localização geográfica, latitude, clima e fotoperíodo) influenciam sob o mesmo, tornando necessário o conhecimento do processo para auxílio em diferenciar um neonato pré-maturo de dismaturo. 0 objetivo deste trabalho foi comprovar se a espécie do reprodutor e se o sexo da progênie do acasalamento influencia no período de gestação (dias) das éguas. Foram utilizados dados retrospectivos de 60 éguas mestiças, Puro Sangue Inglês (PSI) e Brasileiro de Hipismo (BH), com faixa etária entre 2 e 23 anos, ao longo de 10 estações reprodutivas, pertencentes ao Setor de Equideocultura da Prefeitura do Campus Fernando Costa da Universidade de São Paulo, Pirassununga/SP. O estudo procedeu-se por meio da separação dos dados das éguas em categorias: éguas cobertas ou inseminadas com garanhão ou jumento; sexo da cria obtida quando o reprodutor foi garanhão ou jumento; duração do período de gestação de acordo com a faixa etária das éguas, sendo estas divididas em 3 grupos: éguas de 2 a 4, 5 a 8 e 9 a 23 anos. Foram utilizados 13 garanhões e 2 jumentos como reprodutores ao longo dessas estações. Para análise estatística utilizou-se o procedimento MIXED do SAS, versão 9.3. Os efeitos de sexo, espécie e idade foram analisados separadamente. Quando necessário, o teste de médias LSD foi utilizado nas comparações. Não houve diferença significativa $(P>0,05)$ no tempo de gestação de éguas prenhes de híbridos (burro ou mula) ou não (potro ou potra), tampouco no sexo da cria, sendo a média de gestação geral de 330,9 \pm 1,19 dias quando macho (328,5 a 333,2 dias), e 327,9 \pm 1,09 dias quando fêmea (325,7 a 330,1 dias). Não houve efeito significativo $(\mathrm{P}>0,05)$ da espécie do reprodutor no tempo de gestação das éguas, independendo do sexo do produto; 329,5 \pm 0,91 dias (327,7 a 331,3 dias) quando era garanhão e 328,1 \pm 1,83 dias (324,5 a 331,8 dias) quando o reprodutor era jumento. 0 tempo de gestação foi significativamente $(\mathrm{P}<0,05)$ maior em éguas de 9 a 23 anos de idade $(333,5 \pm 1,74$ dias $)$, porém 
éguas de 2 a 4 e 5 a 8 anos de idade não diferiram significativamente $(P>0,05)$ quando comparadas entre si, tendo obtido médias de $327,7 \pm 1,24$ dias e $328,6 \pm 1,27$ dias, respectivamente. A variação no tempo de gestação é grande devido a vários fatores influenciando, tendo sido reportado médias de 338,0 \pm 0,68 dias em éguas da raça Mangalarga. Não foi encontrada diferença significativa $(P>0,05)$ no período gestacional de potras das raças Mangalarga (340,3 dias) e Bretão (338,1 dias), bem como efeito do sexo da cria, no entanto notou-se uma significativa variação no período de gestação da raça Mangalarga quando comparado o mês de concepção, sendo menor no mês de janeiro (330,75 dias) e maior em outubro (343 dias); já na raça Bretão, a variação em dias foi menor, sendo maior no mês de fevereiro (337,9 dias) e menor também em outubro $(342,9$ dias). Ainda há relatada uma tendência $(\mathrm{P}=0,074)$ de éguas primíparas apresentarem período gestacional maior que multíparas na raça Crioula, tendo como média geral 335,6 \pm 10,5 dias (312 a 364 dias). Foi também constatado que quando o sexo da progênie foi masculino, o período gestacional foi significativamente $(\mathrm{P}<0,001)$ maior $(346,2 \pm 0,72$ dias $)$ quando comparado as do sexo feminino $(342,4$ $\pm 0,65$ dias) em éguas da raça Puro Sangue Inglês criadas no Reino Unido. Entretanto, quando se trata de éguas cobertas por jumentos, a literatura é bastante escassa e superficial; neste sentido, é relatado que éguas prenhes de híbridos têm um período de gestação de 343,1 dias (315 a 369 dias). Ficou claro neste estudo que a espécie do reprodutor, seja garanhão ou jumento, não interfere no tempo de gestação, tampouco o sexo da cria influencia em tal circunstância. Sendo assim, a idade da égua parece causar maior interferência na duração do período de gestação.

Palavras-chave: Gestação. Híbridos. Garanhões. 